\title{
La Fiesta de la Tarántula: júbilo y congoja en el Alto Aragón
}

\author{
The Tarantula Festival: \\ Joy and Distress in Upper Aragon
}

María Tausiet

CCHS. CSIC. Madrid

\section{RESUMEN}

El tarantismo (fenómeno mítico-ritual según el cual quienes eran picados por la temida tarántula sólo podían recuperarse mediante la música y el baile) se manifestó desde antiguo en Italia, pero también en España, donde no ha sido tan estudiado, al menos desde la perspectiva de la historia cultural. De la vigencia de dicho fenómeno en Aragón hasta bien entrado el siglo xx dan cuenta las entrevistas en Fraga (Huesca) con varios informantes acerca de la llamada "Fiesta de la Tarántula": una forma comunitaria de exorcizar todo tipo de desgracias individuales, gracias al poder de la compasión y la solidaridad vecinal.

Palabras clave: Tarantismo, Musicoterapia, Danzaterapia, Jota, Araña Mítica, Posesión Demoníaca, Fiestas Tradicionales.

\section{SUMMARY}

Tarantism (a mythically-based, ritualized reaction to the bite of the dreaded tarantula in the belief that the victim could only be cured by music and dance) had existed in Italy since time immemorial; yet it manifested itself also in Spain, where it has been far less studied, at least from the perspective of cultural history. Tarantism was certainly known in Aragon until well into the $20^{\text {th }}$ century, as reported by informants in Fraga (Huesca) who recall "The Tarantula Festival," by which all forms of individual suffering were communally exorcised through the power of sympathy and neighbourly solidarity.

Key words: Tarantism, Music Therapy, Dance Therapy, Jota, Mythical Spider, Demonic Possession, Traditional festivals. 
"Con un ojo reír y con otro llorar" 1

La tarántula, ese "ponzoñoso insecto" que, en palabras del doctor Francisco Xavier Cid, provocaba "una picadura aguda bastante dolorosa", pero también otros síntomas mucho más ambiguos como "ansias, congojas, suma inquietud", "desazón interior", "desasosiego" o incluso "melancolía", campó por sus respetos en el sur de Italia durante mucho tiempo. No obstante, como el propio Cid se propuso demostrar a finales del siglo XVIII, su presencia en España era asimismo palpable, y no sólo eso, sino que, al igual que en Italia, la música y el baile constituían el recurso más utilizado para paliar sus temidos efectos.

La inspirada obra de Cid, una joya temprana de la antropología europea cuyo relativismo cultural superaba los fines de los tratados médicos al uso, iba más allá de la dicotomía falso/verdadero, característica del llamado Siglo de las Luces. Frente a la polémica en torno a la impostura o la realidad del tarantismo ibérico —es decir, del fenómeno que englobaba el veneno y la enfermedad, así como el remedio para combatirla- el propio Cid afirmaba:

no es que unos mientan y otros digan la verdad; no el que no haya tal veneno como pudieran inferir los críticos vulgares; no el que se exageren demasiado sus producidos [...]; sino que la precisa desigualdad de los países, la idiosincrasia del insecto y del mordido, y otro cúmulo de circunstancias que alteran generalmente las cualidades de los cuerpos, son la verdadera causa de haber faltado en el presente suceso muchas de las notadas por los médicos italianos (Cid 1787: 226).

Efectivamente, el tarantismo español presentaba rasgos propios, que no dejaban de resultar extraordinarios, lo que llevó a muchos escépticos a afirmar que se trataba de un fenómeno fingido o fabuloso. Frente a tales opiniones y basándose en tres casos observados por su padre a mediados del siglo XIX, otro médico, Carlos Mestre y Marzal, defendía la necesidad de hacer un esfuerzo adicional para entender precisamente aquello que los prejuicios de la razón tienden a rechazar como imposible:

Hay ciertos hechos que, o por poco frecuentes o porque desde luego se les miró con cierta indiferencia, se encuentran o mal estudiados o tal vez echados en el olvido [...] Algunos de estos hechos, sobre ser sorprendentes y hasta maravillosos, se ven desgraciadamente descuidados y, no pudiendo darnos la solución completa de ellos a pesar de observarlos, queremos persuadirnos de que no existen, por no confesar nuestra ignorancia o nuestra apatía. El tarantulismo está in-

\footnotetext{
${ }^{1}$ Junceda (1998: 13 y 66).
} 
cluido entre estos fenómenos y [...] se encuentra, aún en nuestros días, tenido como una fábula (Mestre 1843: 6-7).

Sin alcanzar la extravagancia de los comportamientos de los atarantados descritos por Athanasius Kircher (1643) o Giorgio Baglivi (1696) —entre otros, colgarse de los árboles boca abajo a imitación de las arañas, tenderse en los sepulcros, arrojarse a los pozos, ponerse vestidos rojos, manejar espadas o mirarse obsesivamente al espejo-, los síntomas asociados a los ejemplos observados en España resultaban asimismo asombrosos. Al margen de lo pintoresco de cada caso particular, lo más llamativo era la aparente compatibilidad de sentimientos encontrados, esa mezcla de excitación y depresión que en su día llevara a Kircher a calificar el tarantismo de "alegre miseria" (Kircher 1643: 768).

Uno de los casos más representativos de dicha paradoja es sin duda el atendido y estudiado en 1787 por Bartolomé Piñera y Siles en el Hospital General de Madrid. Ambrosio Silván, un muchacho de catorce años, había ingresado el 25 de junio, convulso y delirante, y no saldría hasta el 5 de septiembre, una vez curado de la picadura de la tarántula supuestamente causante de sus males. Tras serle aplicados distintos remedios como sangrías, enemas, dietas o alcanfor, los únicos que se probaron efectivos fueron la música y el baile, cuya interpretación tuvo lugar en el mismo hospital, gracias al empeño del doctor Piñera: "Encontré una absoluta oposición alegando varias razones, siendo la más poderosa que en un hospital no se debia aplicar un remedio como la música, y que si no surtia efecto nos expondríamos a la sátira, mofa e irrisión de la Corte" (Piñera y Siles 1787: 14). Éste consiguió que acudiera a los pies de la cama del muchacho un vecino suyo de Valdepeñas (Ciudad Real) para tocarle la tarantela con su vihuela. A partir de ese momento, Ambrosio empezó a moverse progresivamente hasta terminar bailando con regularidad durante varias semanas. Tal y como detallaba Piñera en el diario que escribió sobre el paciente:

Causaba compasión el contraste de afectos que se advertían en el Ambrosio: ya lleno de satisfacción manifestaba cierto aire risueño, ya exhalaba los más agudos suspiros y ayes (Piñera y Siles 1787: 17).

Todavía un mes después de empezar a serle aplicada su cura coreográfico-musical, el muchacho seguía "agitado de un torrente de afectos y movimientos irregulares", aunque no por ello dejara de "bailar sin perder el compás [...] enfadado, y alguna vez lloroso". El hecho de "bailar llorando" (Piñera y Siles 1787: 29 y 31) volvía a ser destacado casi un siglo después en el tratado sobre el tarantismo de Mestre, según el cual, "el enfermo se encuentra como combatido de dos afectos distintos [...] mezclando así su placer con su tristeza" (Mestre 1843: 24-25). 
La unión inseparable de sensaciones físicas con una extensa gama de contenidos psíquicos y emociones complejas en los síntomas de los atarantados plantea la necesidad de abordar el tarantismo español desde el punto de vista de la historia cultural, más allá de la perspectiva médico-científica que ha predominado en la literatura dedicada al tema a partir del siglo XVIII ${ }^{2}$. Sin ocultar el subjetivismo inherente a toda aproximación antropológica, he de reconocer que mi interés personal por el tarantismo arranca de dos fuentes. Por un lado, de mi dedicación a la investigación sobre la brujería y la posesión demoníaca en Aragón entre los siglos XVI y XIX. Por otro, de mi experiencia como testigo privilegiada de los últimos vestigios de la creencia y la práctica del tarantismo en la localidad de Fraga (Huesca) ${ }^{3}$, gracias a las entrevistas realizadas en 1999 y 2000 a algunos de los protagonistas y partícipes de un fenómeno que se prolongó hasta los años cuarenta del siglo xx, y que hoy en día tan solo permanece en la memoria de unos pocos.

El vínculo entre la brujería y el tarantismo, pese a las diferencias obvias, resulta incuestionable (Tamblé 2000: 101-117). Tanto a la bruja como a la tarántula se las consideraba portadoras de veneno en su doble vertiente: material y simbólica. No en vano, entre las expresiones más antiguas utilizadas para designar lo que más tarde acabaría generalizándose como brujería se encuentran términos como "metzineria", "ponzoñeria" o "erbole-

${ }^{2}$ Conviene recordar que, ya desde los siglos XVI y XVII, aparecen algunas interesantes menciones al tarantismo en la obra de varios autores españoles. Entre ellos, Pedro Mexía (Silva de varia lección, 1540), Oliva Sabuco de Nantes (Nueva filosofía de la naturaleza del hombre, 1587) y Sebastián de Covarrubias (Tesoro de la lengua castellana o española, 1611). Durante los siglos XVIII y XIX, pese a la riqueza antropológica de algunos ensayos, la visión médica del tarantismo español resulta patente al repasar la lista de tratados que abordan el tema extensamente. Para los pertenecientes al siglo XVIII, véase Pilar León Sanz (1991). Para el siglo XIX, véase asimismo la bibliografía aportada por León Sanz (2000). Dicho enfoque continuó prevaleciendo a lo largo del siglo xx y comienzos del XXI, aunque a partir de los años cuarenta empiezan a aparecer algunos trabajos realizados desde el punto de vista de la etnomusicología. Entre ellos, destaca la obra de Marius Schneider (1948). Véanse también Ángel González Palencia (1944-45); Luis Robledo (1979-1980); José Manuel Almendros Toledo (1987); Joaquín Álvarez Barrientos (1988); Pilar León Sanz (1997); Ascensión García de las Mozas y Adriano López Sánchez (1999 y 2000). Una buena panorámica del tarantismo español es el reciente artículo de Anna Gruszczyñska-Ziólkowska (2007).

${ }^{3}$ La localidad de Fraga es la capital de la comarca del Bajo o Baix Cinca, una de las diez que forman el Alto Aragón (o zona septentrional de Aragón que suele considerarse equivalente a la provincia de Huesca), junto con Jacetania, Alto Gállego, Sobrarbe, Ribagorza, Hoya de Huesca, Somontano de Barbastro, Cinca Medio, La Litera y Monegros. 
ria”, que no eran sino sinónimos de envenenamiento ${ }^{4}$. La idea de maleficio (maleficium) se asimilaba a la de veneno (veneficium) hasta el punto de que, en palabras del humanista Pedro Mexía, "ay personas [...] que tienen ponzoña en los ojos”, una imagen inequívoca de la creencia en el poder destructivo de la mala intención expresada a través de la mirada (Mexía 1989: 411) $)^{5}$. Sin salir del ámbito de lo simbólico, conviene recordar que en el primer documento conservado en Europa sobre el tarantismo, del siglo XIV, el veneno de las tarántulas aparecía asociado no sólo a animales reales, como los perros rabiosos, sino también a otros estrictamente fabulosos, como el basilisco ${ }^{6}$.

En cuanto a la relación entre posesión y tarantismo, las afinidades resultan todavía más acusadas, pues algunos de los síntomas característicos de los atarantados (pérdida de conciencia, movimientos convulsivos, descontrol, agresividad, delirios) coincidían con los de los pretendidos endemoniados. Para Ernesto De Martino, clasificar el tarantismo como un caso particular de posesión supondría una explicación reduccionista. No obstante, él mismo se refirió al fenómeno como "una posesión de tipo animal", y al atarantado como "una víctima poseída por la bestia" (De Martino 1999: 195, 217 y 63). Según Gilbert Rouget, el tarantismo constituía un claro ejemplo de "posesión identificatoria", en este caso con la araña que habría venido a habitar temporalmente el cuerpo del picado. De ese modo se explicaría la imitación de los movimientos de la tarántula por parte de sus víctimas y/o allegados, lo que obligaría a considerar el tarantismo no tanto un rito de expulsión ("exorcismo") como de conciliación ("adorcismo") (Rouget 2000: 43-52). En cualquier caso — como veremos más adelante en Fraga-, al igual que la posesión demoníaca, el tarantismo representaba una terapia más que una enfermedad, ya que ofrecía la oportunidad de liberar tensiones acumuladas, además de suponer una excelente disculpa (admitida socialmente) para que los atarantados pudieran mostrar en público una hostilidad — con fre-

\footnotetext{
${ }^{4}$ Según Christian Desplat, en Francia, durante el Antiguo Régimen, gran parte de los vocablos utilizados para designar a brujas y brujos tenían relación con el envenenamiento ("posoere" o "pousouere"). Algo similar puede afirmarse para Aragón, especialmente en la zona pirenaica, como puede comprobarse en las expresiones referidas a la brujería en los estatutos de desaforamiento contra dicho crimen ("bruxeria y metzineria, sortilleria y ponzoñeria"). (Véanse Desplat 2001: 160-164, y Tausiet 2004: 195-218).

${ }^{5}$ En la misma obra, Mexía se refería al veneno de la tarántula como "maldita ponçoña" que "se gasta" bailando al son de "vihuelas, flautas y otros instrumentos" (Mexía 1989: 87).

${ }^{6}$ El documento referido es el tratado de Guglielmo De Marra, dedicado al papa Urbano V, que lleva por título Sertum papale de venenis (1362) (véase De Martino 1999: 185-186 y 250-255). Sobre la literatura de venenos véase Turchini (1987).
} 
cuencia hacia sus parientes más cercanos- que no les era permitida en la vida normal.

Dichos comportamientos nos remiten inevitablemente a los manifestados en el Alto Aragón hasta los años cuarenta del siglo xx por las llamadas "espiritadas de Santa Orosia". Las crisis de posesión demoníaca de quienes acudían desde sus lugares de origen hasta la catedral de Jaca (Huesca) cada 25 de junio para liberarse de sus "demonios" tenían no pocos aspectos en común con las crisis de los picados de la tarántula, pese a la distancia entre ambos fenómenos. En los dos casos, el momento en que se exteriorizaban era la época estival, un período especialmente crítico que, como señalaba De Martino, suponía enfrentarse al "vacío vegetal y laboral posterior a la época de la cosecha" y "desafiar la inseguridad del nuevo año agrícola". Para el antropólogo italiano, el verano representaba un período de tensión social muy marcada, un "tiempo simbólico de impedimentos existenciales" que se transmutaba fácilmente en "una época de eflorescencia de todos los conflictos sin resolver" (De Martino 1999: 168).

A diferencia de los episodios de posesión demoníaca, virtualmente intemporales, dada la naturaleza imaginaria de su agente, los episodios de tarantismo tenían lugar en verano por una razón de tipo material. Era entonces cuando se multiplicaban las ocasiones de picadura real de las arañas (latrodectismo) durante los diversos trabajos de recolección agrícola. La siega, el espigueo o la vendimia coincidían con el momento en que los arácnidos venenosos eran más numerosos y se encontraban más activos. Ello no significa que el tarantismo no albergara un componente imaginario o simbólico, más allá del envenenamiento físico. De hecho, tal y como se deduce por los testimonios recogidos en Fraga, todo el dispositivo cultural en torno a la picadura de la tarántula (animal que podemos considerar mítico, pues no se corresponde con ninguna especie de araña en particular ${ }^{9}$ ) se hallaba dirigido a mitigar un dolor a la vez físico y espiritual.

7 En 1947 el obispo de Jaca, José Bueno Monreal, prohibió la asistencia de endemoniados a la procesión de Santa Orosia, por considerar que las exhibiciones histéricas de los enfermos perjudicaban el acto religioso (Satué Oliván 1988).

${ }^{8}$ Conviene hacer notar que en la localidad de Tosos (Zaragoza), los períodos agudos de otro impactante episodio de posesión demoníaca tuvieron lugar asimismo durante los meses de verano de los años 1812, 1813 y 1814 (véase Tausiet 2002).

9 Como apuntaba De Martino, la tarántula no se corresponde con ninguna araña de la zoología moderna, aunque existe cierta tendencia a que la mítica tarántula se identifique con una especie particular de arañas (lycosa tarentula) de aspecto espectacular (oscuras, gruesas, velludas) y, por tanto, capaces de representar las tentaciones del inconsciente. Sin embargo, otros arácnidos, como el escorpión (y, a veces, incluso serpientes o alacranes) son denominadas también tarántulas (De Martino 1999: 59-63). Se- 
La forma de consolar al sufriente, es decir, la fiesta de la tarántula celebrada en torno a su lecho, resulta completamente extraña para nuestra mentalidad actual, caracterizada en gran medida por el individualismo y la simulación. Frente a los gestos cariacontecidos exhibidos habitualmente hoy en día ante los enfermos, la alegría real de los implicados en los episodios de tarantismo nos parece casi cruel. Se trata de un sentimiento que se opone por completo a la exclamación lanzada por un pastor de Lotzorai (Cerdeña) en 1943, relativa a la curación de su picadura: "Sentía la risa [de los otros] como un soplo que me refrescaba y que me aliviaba cada vez un poco más!” (Gallini 1988: 169). A pesar de la cercanía temporal, como ha escrito el dramaturgo Alan Bennett, "no hay ninguna época tan remota como el pasado reciente"10. En ese sentido, los testimonios de tarantismo recogidos en Fraga reflejan un tipo de cultura tradicional cuyos valores eran tan diferentes a los nuestros que nos cuesta creer que hayan sido compartidos por algunos de nuestros contemporáneos. En cuanto a la capacidad curativa de los remedios contra el mal de la tarántula, su eficacia simbólica irá descubriéndose a través de las informaciones de quienes amablemente accedieron a compartir conmigo sus recuerdos y opiniones.

\section{El CASO DE Fraga}

Las primeras entrevistas, realizadas en Zaragoza a lo largo del verano de 1999 a varios miembros de la familia Salarrullana, supusieron un excelente punto de partida ${ }^{11}$. El 11 de julio de 2000 se vieron continuadas con nuevas informaciones procedentes de ocho testigos más residentes en Fraga ${ }^{12}$. Entre ellos, destaca el testimonio de Pedro Agustín Pérez, alias Lifonso, "el

gún las informaciones recogidas en Fraga, más bien confusas, existían varias clases de tarántulas: "Había una que llevaba más veneno, pero ésa no llevaba guitarra en el cuerpo. Las que picaban eran de color oscuro" (Jorge Costa); "Eran bichos así de gordos [señalando medio dedo pulgar]" (Pedro Agustín Pérez).

10 "There is no period so remote as the recent past", en el inglés original. La cita pertenece a la obra The history boys, estrenada en el National Theatre de Londres en mayo de 2004.

${ }^{11}$ Los cuatro hermanos Salarrullana Verdú, originarios de Fraga y entrevistados en primer lugar, cuya fecha de nacimiento figura entre paréntesis, fueron: Conchita (1919), José (1921), Carmen (1928) y María Pilar (1930). Mi sincero agradecimiento a Begoña Chaves Salarrullana por haberme puesto en contacto con todos ellos.

12 Dichos informantes, con su fecha de nacimiento entre paréntesis, fueron: Carmen Morer Casas (1913), Juan Antonio Labrador Espitia (1919), Joaquín Benedicto Agustín (1920), Pedro Agustín Pérez (1920), Francisca Alba (1925), Andresa Beán (1933), Jorge Costa Casas (1933) y Agustín Cabrera (1938). 
último picado de la tarántula" del que se conserva memoria, a quien tuve la suerte de conocer antes de su fallecimiento en $2004^{13}$. A los datos aportados por los citados informantes hay que añadir el sainete titulado La tarántula, escrito en 1998 por Andreseta y Pepeta Beán en dialecto fragatino ${ }^{14}$, cuyo acierto en la reconstrucción del paradigma de tarantismo local y cuya sensibilidad hacia las repercusiones individuales y colectivas del fenómeno no me cansaré de elogiar.

Todos los entrevistados coincidieron en afirmar que la tarántula picaba en verano y en el campo ("el monte" o "las eras") durante los trabajos de la cosecha, habitualmente mientras el afectado dormía o descansaba junto a las gavillas. Los dolores provocados por la picadura eran tan agudos que se comparaban a los del "cólico miserere", nombre dado a una oclusión intestinal gravísima cuando se pensaba que el único remedio posible era rezar (de "miserere", palabra con que comienza el Salmo núm. 50, que quiere decir: "Ten piedad"). Lo primero que debía hacerse era trasladar al "picado" hasta Fraga en un carro lo antes posible para, una vez allí, tumbarlo en un colchón a la vista de todo el pueblo. Éste se colocaba bien en el patio de su casa, bien en la calle. Lo importante era que acudiera el máximo número de vecinos a cantar y a bailar alrededor del enfermo, acompañados de guitarras y otros instrumentos. En compensación, la familia del atarantado ofrecía un banquete a los asistentes, consistente en aceitunas, vino y embutidos (jamón, longaniza, chorizo, etc.). Ello suponía en más de una ocasión la ruina de las familias pobres, dada la numerosa concurrencia, que en varias horas podía agotar las reservas guardadas para todo el año.

Exceptuando la preocupación de los familiares más cercanos, para la mayoría se trataba, ante todo, de una fiesta ${ }^{15}$, una distracción en medio de

\footnotetext{
${ }^{13}$ Carmen Morer, Juan Antonio Labrador, Francisca Alba y Joaquín Benedicto aportaron también los nombres de otras seis personas "picadas por la tarántula", por desgracia ya fallecidas cuando realicé las entrevistas en el año 2000: Rafaela Faire Mestres, la Mañaba; Francisco Costa Corbella; Salvador, el de Tono; Mariano Morer, el Retoro; Teresa Claramunt, la Tulona; y La Mullarera.

${ }^{14}$ Agradezco la disponibilidad y la generosidad de Ángel Hernández, que amablemente me sirvió de introductor con los entrevistados durante mi estancia en Fraga. Él es también el traductor de todas las citas pertenecientes a la obra La Tarántula que figuran a pie de página en castellano a lo largo del artículo.

15 "Para la gente era una fiesta: no lloraba nadie" (Conchita Salarrullana). En julio de 1937, en plena Guerra Civil española, la llamada Columna Durruti (integrada por milicianos anarquistas) se hizo con el dominio de Fraga durante unos meses, llevándose a cabo una colectivización que abolió la propiedad privada, el dinero y el trabajo asalariado: "Se vivía sin dinero, todo se apuntaba en una libreta; además no había ni cine, ni baile, ni nada. La picadura de la tarántula fue ese año una auténtica fiesta en ausencia de otras diversiones [...]. Muchos milicianos iban allí de juerga, al patio de la casa" (José Salarrullana).
} 


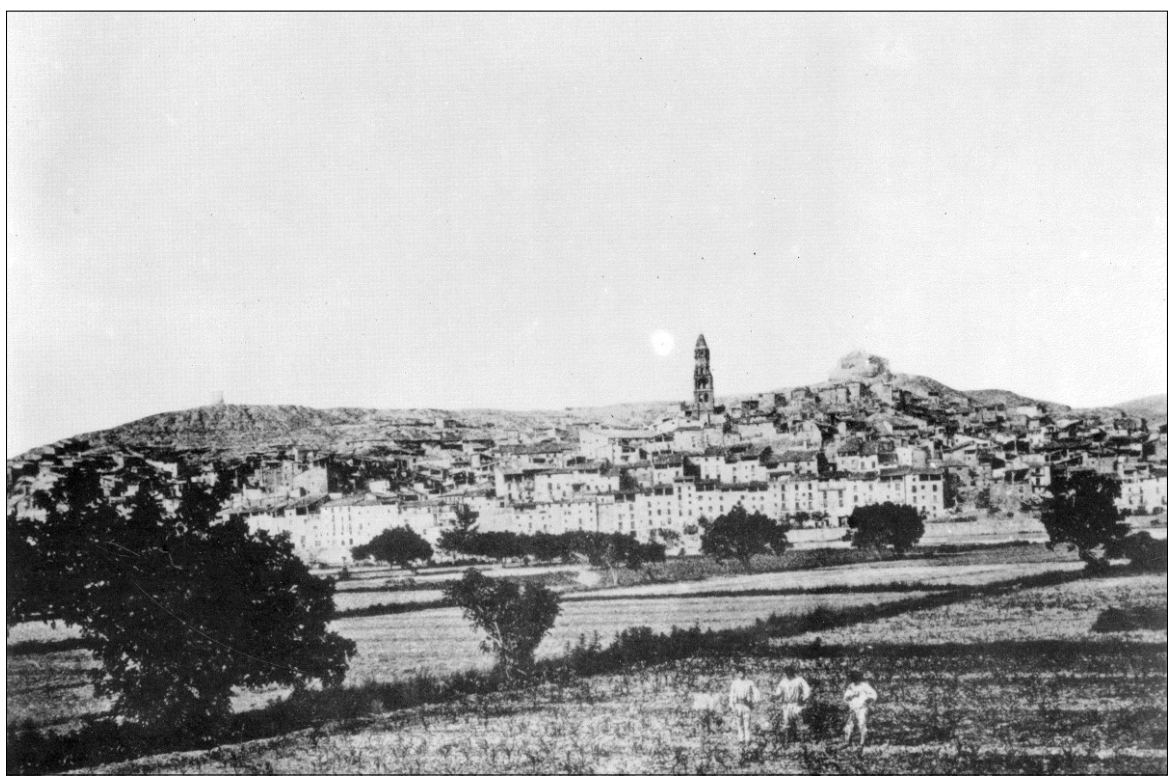

Fig. 1. La huerta fragatina, con la ciudad de Fraga al fondo. 1908.

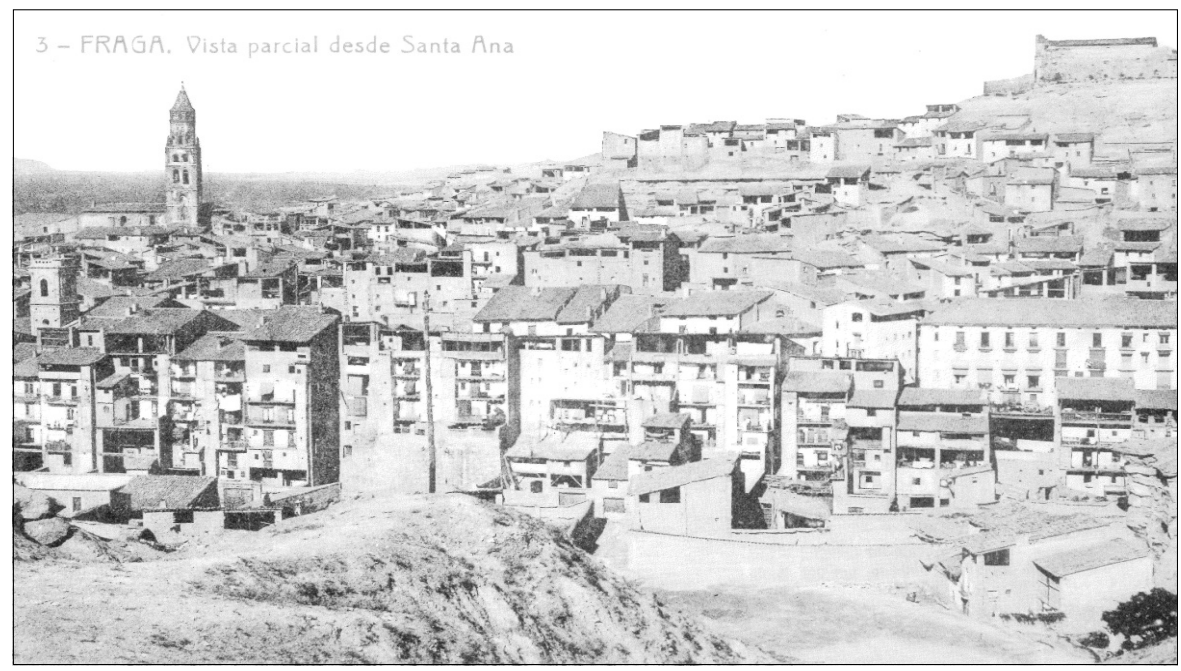

FIG. 2. Fraga. Vista parcial desde Santa Ana. 1925. 
las pesadas labores agrícolas y una buena excusa para desarrollar la sociabilidad, e incluso la posibilidad de emparejarse. Ello no excluía el aspecto trascendente de la diversión: una forma comunitaria de exorcizar la desgracia. Como han puesto de manifiesto quienes han investigado el fenómeno en otras áreas culturales, la picadura de la tarántula y la consiguiente búsqueda de remedios contra el dolor causado por el insecto coincidían siempre con momentos críticos en la vida de sus víctimas, ya fuera por conflictos familiares, muerte de seres queridos, miseria, hambre, enfermedad y, sobre todo, por la elevada cantidad de frustraciones y contratiempos amorosos.

Para Ernesto de Martino, el tarantismo era no tanto una enfermedad (física o psíquica) como un dispositivo cultural de evocación y alivio; un instrumento de reintegración que encauzaba las crisis del individuo asignándole lugares, tiempos y modos determinados, hasta lograr un nuevo equilibrio. La picadura de la araña, con todas las ceremonias dirigidas a combatirla, supondría, por tanto, un sistema para reconfigurar ciertas dificultades personales de manera que los contenidos psíquicos conflictivos, en lugar de manifestarse como neurosis individuales sin horizonte, pudieran modelarse en un plano simbólico, dentro del marco mítico-ritual de la vida comunitaria.

Ello significa que, pese a la abundancia de rasgos comunes, el tarantismo se manifestaba de forma diferente según las creencias y costumbres de cada localidad o área cultural. Así, por ejemplo, mientras lo característico en el sur de Italia era que las víctimas de la tarántula (en su mayoría, mujeres) bailasen y brincasen hasta caer exhaustas, en la isla de Cerdeña, los picados (en su mayoría varones) apenas se movían, limitándose a recibir los efectos benéficos de la música y las danzas interpretadas en derredor. Idéntica inactividad se observa en buena parte de los casos estudiados en España, y, en particular, en la totalidad de los referidos a Fraga. La explicación más sencilla respecto al sexo de las víctimas es que, tanto en Cerdeña como en muchas áreas españolas, el complejo simbólico-ritual del tarantismo se elaboraba en torno a casos reales de intoxicación o latrodectismo, asociados al trabajo de los campos, predominantemente masculino. Ello explicaría la combinación de síntomas estríctamente físicos (como dolores abdominales) con otros de índole psicosomática (como angustia, depresión e incluso sensación de muerte inminente).

En cuanto a la actitud pasiva de los picados, según el doctor Francisco Xavier Cid, "no siempre la música produce el bayle. Alguna vez no hizo mas que recrear al enfermo, disipar la tristeza, y calmar a manera de encanto todos los fenómenos morbosos" (Cid 1787: 101). De entre los treinta y cinco casos de atarantados españoles analizados en su tratado, había quienes al escuchar el son de la música no sólo no bailaban, sino que alcanza- 
ban una inmovilidad extrema que Cid equiparaba a auténticos éxtasis ${ }^{16}$. Así, por ejemplo, en 1764 un tarantulado de la villa de Montemolín, del partido de Llerena (Extremadura), tras escuchar "el son de la tarantela", quedó en

una perfecta quietud, y el semblante se componía manifestando por él no solamente el dicho sosiego, sino también una notable alegría. En este éxtasis (permítaseme usar de esta voz) ni movía pie ni mano, ni hizo algún otro movimiento sensible (Cid 1787: 211-212).

Del mismo modo, aunque casi siempre era el ritmo de la tarantela ${ }^{17}$ lo que, según Cid (1787: 15-22), calmaba los dolores de los picados, en ciertos casos, como el de un atarantado de Arisgotas (Toledo), su consuelo había sido tan original como inesperado:

Le vio sumamente acongojado y lleno de fatigas con encendimiento [...] le había picado [...] un bicho, lo que inmediatamente le causó un ardor grande e inquietud [...]. El bicho o insecto, que guardaba en un zapato medio estruxado, tenia configuración de araña grande [...] y únicamente el agua le había dado algún alivio [...] con el canto de las golondrinas [...]. Acordaron que saliese el enfermo donde hubiera gentes con quienes pudiera divertirse, y [...] fue al río, donde oyó cantar con gran complacencia a las lavanderas, cuyo canto conocidamente le aliviaba y le desvanecía aquella melancolia, interior desazón o ansiedad [...]. Pero sobre todo, lo que mas calmaba sus síntomas era el canto de las golondrinas (Cid 1787: 215-217).

Para Cid, tales remedios eran inexplicables pero ciertos, lo que le llevaba a asociarlos a otro ejemplo de curación musical consignado en su libro y procedente de las Memorias de la Academia de las Ciencias de París:

un joven con una calentura remitente, que le causaba todas las tardes un dolor de cabeza violento, no podía descansar sino con el ruido de un tambor. Así que sus amigos, para contentarle, estaban precisados a tocarle en el aposento; y este ruido, que aturdía a todos, procuraba al enfermo un alivio maravilloso, aunque en estado de salud no gustase de la música, y mucho menos de la de esta naturaleza (Cid 1787: 214).

${ }^{16}$ Sobre las diferencias entre trance y éxtasis, véase Rouget (1990: 40-55).

${ }^{17} \mathrm{La}$ "tarantela" es, en origen, una danza tradicional del sur de Italia, que, al igual que la araña denominada "tarántula", toma su nombre de la ciudad de Tarentum (Taranto). Se ejecuta en compás de 6/8, y su movimiento es animado, aumentando progresivamente la velocidad. Según Francisco Xavier Cid, "en su rigurosa significación, es la sonata con que se despierta del adormecimiento y languor en que caen los mordidos por la tarántula" y presenta aspectos en común con el "fandango, folías, y canaria". En su estudio, centrado en La Mancha, Andalucía y Extremadura, distingue tres tipos de tarantelas utilizadas en la curación del tarantismo. Véase "De la voz tarantela" (Cid 1787: 15-22). 


\section{SANG EN SUC}

Por los testimonios recogidos en los años cuarenta del siglo xx por el antropólogo y musicólogo Marius Schneider, sabemos que el remedio coreográfico-musical aplicado en zonas aragonesas no era la tarantela (como en el sur de Italia y de España), sino la jota:

En Aragón, el baile de la tarántula es una jota, la lengua vernácula de la música aragonesa. Si esto es exacto, hemos de colegir que dos medicinas musicales -la tarantela y la jota- pueden curar la misma enfermedad, aunque tanto difieren la una de la otra en su aspecto melódico. Ahora bien, en nuestro caso, la gran diferencia entre ambos bailes se borra sensiblemente, ya que la jota aragonesa medicinal tiene otro movimiento que la ordinaria. Se toca aquélla mucho más deprisa que la jota corriente (Schneider 1998: 20).

De hecho, la jota (o "baile" ${ }^{18}$ ) característica del Alto Aragón es "viva, alborotadora y saltadora, y se ejecuta a base de agilísimo movimiento sobre la punta de los pies, juego que se denomina matar la araña"19. Schneider se refería a las informaciones de dos mujeres de Sariñena (Huesca), según las cuales "en Aragón el enfermo tampoco baila, sino que guarda cama, y le basta oír la música y ver gran número de bailadores que, danzando y cantando, matan la araña, y con ésta, la enfermedad" (Schneider 1998: 23). Pese a las diferencias entre la tarantela y la jota, las dos se ejecutan en compás de 6/8 y, en opinión de Schneider, ambas son danzas que representan la batalla o lucha contra los espíritus que traen la enfermedad ${ }^{20}$.

En Fraga, la jota constituía el centro indudable de la fiesta de la tarántula ${ }^{21}$. Una vez que el picado era transportado a la localidad desde los campos donde tenía lugar la siega, acudían hasta su lecho no sólo un gran

${ }^{18}$ El verbo arcaico sotar (del latín saltare, o bailar, como el sánscrito sal, o marchar a saltos) significa bailar o danzar. Jotar es, por tanto, saltar con ritmo y la jota vale tanto como baile. Véase Galán Bergua (1966: 77).

19 "Matar la araña", en términos coreográficos, significa mover los pies con rapidez para terminar asentándolos en seco, paso que forma parte de algunas danzas populares de La Mancha (seguidillas de Higueruela), Asturias (vaqueiros de Alzada) y León, además de las jotas aragonesas (Adell Castán y García Rodríguez 1988: 8).

${ }^{20}$ Según Schneider, el movimiento rápido, a veces frenético, de los dos bailes se relaciona con su aspecto de medicina para la psique: "El rasgo capital de las extravagancias medicinales parece ser la locura que deberán fingir tanto el médico como los enfermos" (Schneider 1998: 82).

${ }^{21}$ En palabras de Jorge Costa: "Jotas tenían que ser; no se admitía otro", un ejemplo claro de cómo las crisis de tarantismo se modelaban culturalmente según las tradiciones particulares de cada zona. 


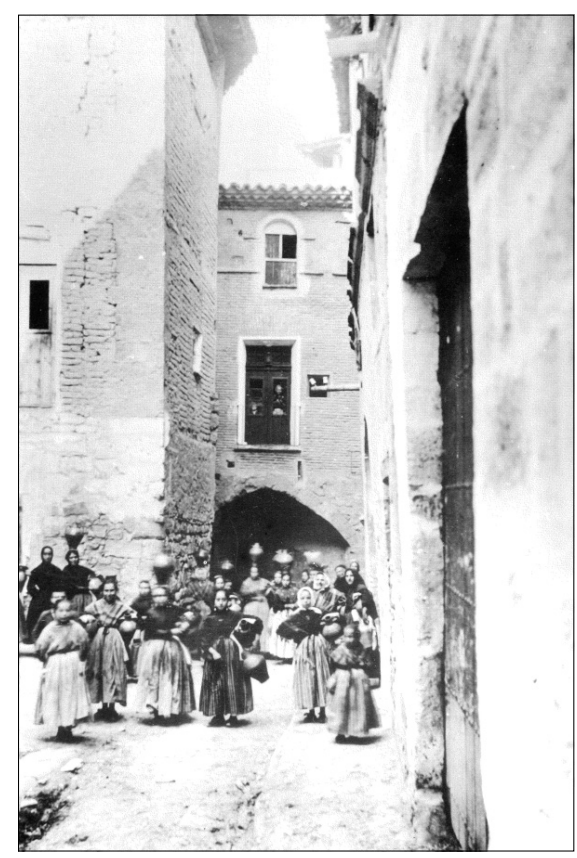

FIG. 3. Varias mujeres y niñas fragatinas en la calle del Barranco. 1920-25.

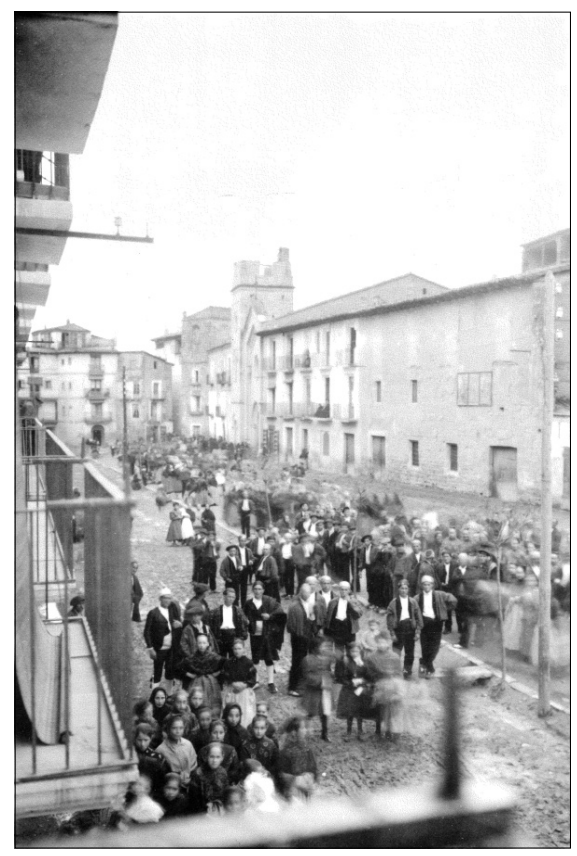

FIG. 4. Día de fiesta en el paseo de Segoñé. 1906.

número de voluntarios, sino también una orquesta o rondalla ${ }^{22}$ integrada por guitarras o por guitarras y bandurrias, a la que la familia del afectado pagaba un salario por su trabajo ${ }^{23}$. El ritmo ternario rápido de los instrumentos de cuerda al interpretar la jota era imitado por las voces de los asistentes produciendo diversas frases onomatopéyicas, como "triqui triquitric", "requetequeteng", "chivirivirí" o "chacarracatán" pero, sobre todo, "sang en suc", expresión a la que me referiré más adelante. Había quienes entonaban jotas conocidas; otros improvisaban letras sobre la marcha; la mayoría simplemente tarareaba acompañando al resto ("nano nano nano nero") (Beán 1998: 18-25).

${ }^{22}$ El término procede de rondar y se aplica a los conjuntos instrumentales de pulso y púa que acompañan a las manifestaciones folklóricas, de manera especial a la jota. Existen rondallas en casi todos los pueblos españoles, y generalmente están constituidas por guitarras solas, o por guitarras, bandurrias y laúdes (Zapater 1988).

${ }^{23}$ Según Andresa Beán, además de los voluntarios y los músicos de la rondalla, "a algunas señoras y señores pobres les pagaban para que fueran a bailar; como en los entierros — donde llevaban una vela y les daban pan-, para que lloraran". Dicha costumbre emparenta el tarantismo con otras formas de duelo, como el lamento ritual. (Véanse De Martino 1975 y Amelang 2005: 3-31). 
Lo importante era no tanto la música como la presencia y la participación de quienes se compadecían del picado y acudían a aliviarle con los medios que tenían a su alcance ${ }^{24}$. De ahí que cualquier objeto sirviera de instrumento improvisado: desde piedras, palos o cencerros hasta utensilios domésticos como sartenes, cubos de metal o "dos cucharitas como castañuelas" 25 . Uno de los lugares comunes era que el sonido de los ejes del carro donde viajaban los picados hasta la población también les proporcionaba un gran alivio ${ }^{26}$. Era tal el efecto apaciguador del ruido y el jolgorio que muchos afectados llegaban incluso a dormirse mientras duraba. No obstante, en cuanto cesaba la música y el alboroto, inmediatamente despertaban de su letargo y se quejaban pidiendo a gritos que no se marchara nadie $^{27}$.

En Fraga, era creencia fundamental que la música y el baile debían prolongarse durante veinticuatro horas ${ }^{28}$. De lo contrario, la acción benéfica desaparecía como por ensalmo, debiendo empezarse de nuevo. Según Jorge Costa y Andresa Beán, la mayoría de los vecinos se retiraban hacia las doce o la una de la madrugada, y eran los familiares, acompañados de algunos voluntarios, quienes se quedaban para consolar y regocijar al enfermo hasta la mañana siguiente. De ahí la conveniencia de ofrecer comida y bebida a quienes velaban, cantando y bailando, toda la noche: "Una vez, pasadas ocho o diez horas, la enferma - Teresa, la Tulona - se puso mejor. Así que pararon de tocar. Pero a las dos o tres horas se puso mucho peor que antes, y hubo que hacer las veinticuatro horas"29.

Mientras tanto, la tarántula acusada del cuadro crítico del atarantado, metida en un vaso de cristal, bailaba también durante veinticuatro horas, arriba y abajo, hasta "reventar". En ese preciso instante, el enfermo se con-

${ }^{24}$ En palabras de Pedro Agustín Pérez: "Era más el ruido que las jotas".

25 Testimonio de Carmen Morer Casas.

26 "Mi abuela me contaba que a su padre le picó la tarántula y lo pusieron al carro, y se quejaba todo el camino. El carro cantaba - ruido característico del juego de los ejes-. Mientras cantaba el carro se aliviaba, pero cuando se atascaba, no. Entonces, el picado gritaba: ¡Haced ruido!, y le cantaban y le tocaban con dos piedras” (Andresa Beán).

27 "Cuando paraban: el desespero". "Mientas cantaban y tocaban, no sentía dolor. Quise probar y ver qué pasaba si paraban. Pero en que dejaron de sonar las cuerdas, me retorcía" (Pedro Agustín Pérez). Según Schneider, "todos los relatos convienen en que, al cesar la música, el enfermo vuelve a sentir sus dolores" (Schneider 1998: 20).

${ }^{28}$ Giorgio Baglivi, en el siglo XVII, mencionaba bailes que duraban de cuatro a seis días. Como destaca Clara Gallini, la danza de la argia, en Cerdeña, duraba tres días. Y, según Marius Schneider, en la provincia de Huesca, la música debía sonar veinticuatro horas (Schneider 1998: 22).

29 Testimonio de Jorge Costa y Andresa Beán. 
sideraba curado $^{30}$. La identificación de la araña con el picado y, a su vez, con la terapia musical que permitía superar la crisis, se traducía asimismo en la creencia de que la tarántula tenía grabada en su dorso la forma de una guitarra: "Se decía que la tarántula llevaba una guitarra en la espalda, y que por eso había que combatirla con otra guitarra" ${ }^{31}$. Según Schneider, la idea según la cual similia similibus curantur (lo semejante se cura con lo semejante) se aplicaba en muchas culturas, no solamente respecto a la música y al baile, sino también respecto al veneno transmitido por ciertos animales, como las serpientes ${ }^{32}$.

La sangre envenenada por la picadura de la tarántula debía restablecerse, por tanto, a las veinticuatro horas, gracias al sudor copioso emitido por el enfermo ${ }^{33}$, a la música y el baile, pero también a las fuerzas que la bebida y la comida proporcionaban a los asistentes. Se creía que la tarántula chupaba la sangre de sus víctimas al igual que se decía que las brujas chupaban la sangre de las criaturas que fallecían prematuramente. La misma imagen se aplicaba a ciertas curanderas codiciosas, a las que se comparaba con auténticas sanguijuelas, que sacaban de sus clientes cuanto podían hasta dejarlos en la ruina ${ }^{34}$.

El motivo central de la sangre curativa $^{35}$ se cifraba en la locución, repe-

\footnotetext{
${ }^{30}$ Jacoba Sarraté, de Sariñena (Huesca) había observado cómo "al oír tocar la música, la tarántula, encerrada en un vaso, se pone a bailar a más no poder. Los músicos han de tocar veinticuatro horas seguidas, hasta que reviente la araña. Muerto este bailarín animal, el enfermo consigue la curación" (Schneider 1998: 21).

31 Testimonio de Conchita Salarrullana.

32 "Para curar a personas mordidas por una serpiente, se ejecutan bailes de serpientes y se emplean unas piedras que las mismas víboras dan: se juntan siete culebras [...], en montón silban, se enroscan, colocan todas su baba sobre la cabeza de una, y la baba enseguida se endurece y se hace piedra por fin [...] Esta piedra, aplicada a la herida, quita el veneno" (Schneider 1998: 83-34).

${ }^{33} \mathrm{Al}$ picado "lo tapaban para que sudase y eliminara el veneno [...]. Interesaba que todo aquel jaleo los atontase, y que sudasen mucho" (Conchita Salarrullana).

${ }^{34}$ La creencia en la brujería y en el mal de ojo, así como la desconfianza en las curanderas que cobraban demasiado por sus servicios, aparece al comienzo de la obra $L a$ Tarántula, como marco para lo que sucederá después. Otro testimonio significativo a propósito de la vigencia hasta bien entrado el siglo xx de la creencia en la brujería en el Alto Aragón es la versión de un cuento tradicional, relatado por "el último picado de la tarántula", Pedro Agustín Pérez. Según su relato, "en Nochebuena cada año se moría una mula en Fraga, y un año un mozo observó en el establo de su casa que había un gato encima de una mula. Entonces, le dio un garrotazo y al día siguiente la abuela apareció con el brazo roto" (Lafoz Rabaza 1990: 64).

35 Acerca de la sangre curativa, la sangre envenenada, y la estrecha relación entre ambas, presente en numerosas leyendas, véase el mito de Asclepio, según el cual Atenea
} 
tida incansablemente por los asistentes a modo de letanía: "Sang en suc, sang en suc, sang en suc...". La frase constituía una redundancia o pleonasmo semántico, pero también fonético (aliteración), de gran expresividad; una suerte de "canto mágico"36 compuesto por palabras aparentemente incomprensibles y, al mismo tiempo, imitativas (del sonido de la guitarra y del ritmo rápido del baile de la araña). Además —a diferencia de otras frases onomatopéyicas tarareadas por los presentes, que también reproducían el sonido de la guitarra al tocar la jota-, dicha expresión tenía un significado traducible: "Sangre en jugo".

Para Jorge Costa y Andresa Beán, "sang en suc" hacía alusión a las vísceras o despojos de los animales — normalmente, del cerdo- una vez sacrificados. En Fraga, al igual que en muchos otros pueblos españoles, tras la matanza se vendían no sólo la carne y las vísceras del animal, sino también la sangre derramada por éste. Las mujeres del pueblo iban a adquirirla a la carnicería, con lecheras en la mano para poder transportarla hasta sus casas: "Era barata y cundía mucho, por eso había fila y muchas riñas". Después se freía en la sartén, habitualmente con cebolla: el resultado era lo que se denominaba sangre en jugo o en salsa, un manjar que, junto con el mondongo, tanto en los duelos como en la fiesta dispuesta alrededor del atarantado, debía durar hasta el último momento: "Como en los velatorios, se guardaba lo mejor para las horas más difíciles" ${ }^{37}$.

\section{MAL DE AMORES}

La picadura de la araña obligaba a sus víctimas a permanecer doloridas y de algún modo paralizadas o en suspenso durante un cierto lapso de tiempo. Según Leonardo da Vinci, "la picadura de la tarántula mantiene al hombre en su propósito, es decir, en lo que pensaba cuando fue picado"38. La misma idea aparecía formulada por Ferdinando Ponzetti unos años más tar-

le dio dos redomas con sangre de la gorgona Medusa. Con una, extraída del lado derecho, podía resucitar a los muertos. Con otra, la del lado izquierdo, matar instantáneamente.

${ }^{36}$ Sobre el "canto mágico", véase L'Échevin (1981: 25-41). Sobre la relación del "canto mágico" con la danza, véase Amades (1949: 349-362). Sobre la "palabra mágica" o curativa, véase Laín Entralgo (1958).

${ }^{37}$ Además de los testimonios citados, Jorge Costa añadió que en el verano de 1945, cuando su abuelo Francisco Costa Corbellá fue picado por la tarántula, los asistentes a la fiesta "acabaron con todo el mondongo del año" y que "lo guardaban para el final, para que no se fueran los voluntarios".

${ }^{38}$ Códice H, fol. 18v. (citado en De Martino 1999: 184). 
de en su tratado sobre venenos: el de la tarántula, por su carácter térreo y adusto, se introducía a través de la piel hasta llegar al cerebro, donde bloqueaba pensamientos y propósitos, haciendo que la víctima perdurara en el estado en que se encontraba en el momento en que había sido picada (Ponzetti 1521).

La tarántula era, por tanto, el "símbolo del pasado malo en el que la vida psíquica ha quedado bloqueada” (De Martino 1999: 188). De ahí que su picadura provocara no sólo un dolor físico, sino también una forma de revivir la angustia ante decisiones no tomadas y ante conflictos, más o menos inconscientes, sin resolver. El dolor espiritual evocado por la picadura de la araña remitía a todo tipo de desgracias, personales y familiares, pero sobre todo solía relacionarse con ciertos desengaños e impedimentos eróticos, "rescoldos de amor", en palabras de Giorgio Baglivi. Según De Martino, el tarantismo podía interpretarse en gran medida como "el exorcismo coreicomusical del eros reprimido" y, al igual que el amor cortés o fin' amors, representaba un sentimiento esencialmente nostálgico (De Martino 1999: 152) ${ }^{39}$.

Los sufrimientos provocados por la pasión amorosa se habían considerado, de hecho, una auténtica enfermedad a lo largo de toda la Edad Media: el llamado "mal de amor" o, en expresión más reciente, "mal de amores". A partir del siglo xv empezó a insistirse cada vez más en la importancia del maleficio (o "mal de ojo") como causa directa del "mal de amor", lo que iba a perdurar, como veremos en Fraga, hasta bien entrado el siglo $\mathrm{xx}^{40}$. En palabras del humanista Pedro Mexía, "el fortissimo afecto del animo y [...] captiverio de la voluntad que llaman amores" no era sino una "enfermedad y passion” y, en sí misma, un peligroso veneno (Mexía 1989: 89).

A diferencia de la investigación realizada en 1959 por De Martino en el sur de Italia, que incluía un detallado análisis de la biografía psíquica de algunas víctimas de la tarántula, carecemos de datos respecto a los avatares de la vida amorosa de los picados en Fraga. Resulta, sin embargo, muy significativo el argumento de la obra teatral La Tarántula, escrita en 1998 por Andreseta y Pepeta Beán, en la que sus autoras trataron de plasmar la esencia del tarantismo mediante una trama ejemplar.

La obra se compone de tres escenas. En la primera, Roque, el futuro atarantado, aparece lloroso y desasosegado porque acaba de dejarle su novia, con quien iba a casarse a finales del verano (29 de septiembre, festividad de San Miguel). Inmediatamente se interpreta que ella ha actuado así

\footnotetext{
39 Acerca del amor cortés, véase Nelli (1963).

${ }^{40}$ Sobre la tendencia, en la Edad Moderna, a medicalizar el amor bajo el concepto de "melancolía erótica", véase Orobitg (1997).
} 


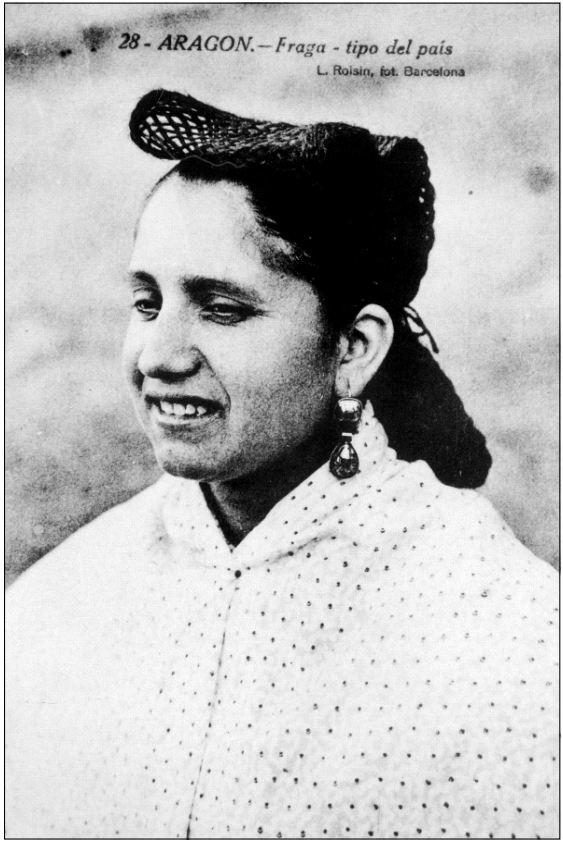

FIG. 5. Fragatina con traje festivo. $1920-25$.

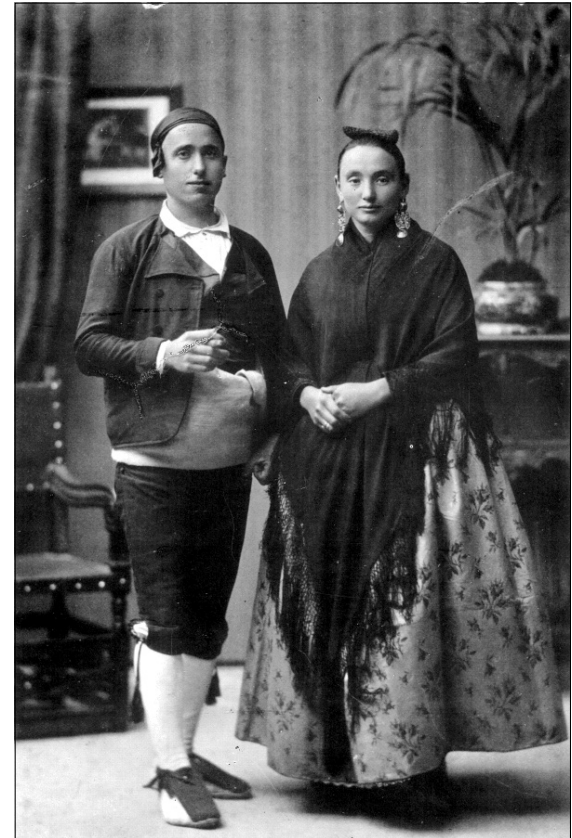

FIG. 6. Pareja fragatina con traje festivo. 1915-1920.

por haber sido embrujada ("a esta chiqueta li han donat mal"41) y que eso la ha trastornado ("perque't volie en locura"42). La llevan entonces a una curandera, que exige ser visitada un día a la semana durante un mes y que se le pague en especie todo lo que pida. Su comportamiento desata el comentario de que las curanderas son como sanguijuelas que arruinan a la gente ("estes chens són com a sangoneres, y ña que s'han arroinat, y no $\mathrm{n}$ 'han tret res" $\left.{ }^{\prime 3}\right)$. Otros remedios, entre la magia y la religión, son utilizados por la madre de la novia sin que ella lo sepa: rociar su cuarto con agua bendita, ponerle una rama de ruda debajo de la cama, etc. Se aconseja a la madre de Roque que introduzca dentro del cinturón de su hijo un mechón sacado del peine de la joven. Otra mujer sugiere que se coloque una vela encendida en el cuarto de la novia, y que en la llave de la puerta le cuelguen un calcetín sucio del novio para que el olor ahuyente a los malos espíritus (Beán 1998: 5).

\footnotetext{
41 "A esta chica le han dado "mal"” (Beán 1998: 4).

42 "Porque te quería con locura" (Beán 1998: 4).

43 "Estas gentes son como sanguijuelas, y hay quienes se han arruinado y no han sacado nada" (Beán 1998: 4).
} 
En la segunda escena, la madre de Roque recibe la noticia de que su hijo ha sido picado por la tarántula, lo que le lleva a lamentar la ruina que el suceso va a suponer para la familia, dado el banquete que van a tener que preparar. El padre ha trasladado en su carro a Roque desde las eras, "en pena y en dolor" ${ }^{44}$; asimismo, le ha cantado y hecho todo el ruido que podía, para aliviar su "congoixa" ${ }^{2}$. Roque se ha dormido un rato, pero el padre ha tenido que parar en cierto momento, con lo que los dolores agudos de la picadura han vuelto a aparecer y el atarantado se ha alborotado. Entonces el padre se ha puesto a cantar y a bailar "com un desesperat" hasta que un joven pastor, compadecido, le ha relevado un rato, bailando la jota con gran salero. Cuando la madre se encuentra en Fraga con su hijo, le recuerda, llorando, todas sus desgracias:

¿Qué t'ha passat, desgraciat? Cuidado que mala pata tens fill, que tot t'acodís. L'hivern passat les tercianes [...] y casi te'n vas anar a l'altre mon, después la patae que't va pegar'l pollí al torterol, y ara que ya havies tret fabes d'olla, t'ha picat la tarantula. Tu si qu'has naixcut pa patir, fill meu del meu cor...y pa acabar-hu d'apañar no't volen a ca la novia, ipobret! ${ }^{47}$.

Roque es colocado en un colchón a la puerta de su casa, desde donde insiste en que no le hablen, sino que se dirijan a él cantando y, a ser posible, bailando ("si han de dir algo, diguem-hu cantando"48). Quien mejor le comprende es Antonio, que le baila y canta sin parar, porque a él también le picó la tarántula cuando era mozo. Antonio cuenta que a él no le llevaron a Fraga, sino que se quedó en el monte acompañado por unos cuantos y que, después de unas horas cantando y bailando, casi todos se fueron a descansar, con lo que se le renovaron los padecimientos, hasta que su padre utilizó un cedazo a modo de pandero para despertarlos.

Mientras tanto, la familia prepara la fiesta y anuncia lo sucedido a la vecindad. Algunas mujeres reciben la noticia mientras están lavando en el río. Nada más saberlo, se deshacen de la cesta donde llevan la ropa y de

${ }^{44}$ Nótese el pleonasmo, en forma de redundancia semántica y fonética, al igual que en la expresión "sang en suc" (Beán 1998:16).

45 "Congoja, angustia” (Beán 1998: 16).

46 "Como un desesperado" (Beán 1998: 16).

47 "¿Qué te ha pasado, desgraciado?, Cuidado que mala pata tienes, hijo, que todo te acude a tí. El invierno pasado las tercianas [...] y casi te vas al otro mundo, después la coz que te pegó el pollino en el tobillo, y ahora que ya habías salido de males, te ha picado la tarántula. Tú sí que has nacido para padecer, hijo mío de mi corazón... y para acabar de estropearlo, no te quieren los de la casa de la novia... ipobrecito!" (Beán 1998: 16-17).

48 "Si han de decir algo, díganmelo cantando" (Beán 1998: 18). 
la losa donde la restriegan, para acudir corriendo a la calle donde vive el atarantado. La reunión promete ser divertida: "Au Carmeta, com a cuan erem joves" ${ }^{49}$.

En la calle, unos tocan la guitarra, otros cantan jotas improvisadas; se baila por turnos, se bebe vino y se comen olivas, jamón y longaniza. Algunos danzan en corro, otros en parejas (cortejando el hombre a la mujer ${ }^{50}$ ). Hay quienes comentan otros casos de tarantismo habidos en el pueblo y cómo a un vecino le picaron dos años seguidos. Una mujer insiste en que no merece la pena avisar al doctor.

En la tercera escena aparece Pepa, una joven que al principio de la obra ya había confesado apreciar más a Roque que a todos los herederos de Fraga. Se hace hincapié en las distintas actitudes de unos y otros respecto a los padecimientos del picado. Los más generosos cantan y bailan para aliviarle, en un gesto de solidaridad. Una mujer, que se retira pronto, es calificada de "bruixa", por su tacañería sentimental. Alguien compara su actitud con la mostrada en el velatorio de su suegra, que abandonó inmediatamente después de tomar la recena de chocolate. La madre de Pepa (futura suegra del atarantado) se niega a acudir, a la vez que manifiesta su resentimiento porque Roque no ha ido nunca a visitarla. Pepa declara su amor a Roque diciéndole que le cantará y bailará cuanto sea necesario:

No plores, Roque, quém trenques lo cor. Ya cantaré y ballaré sense parar, hasta que te se passe ${ }^{51}$.

La ambigüedad entre los síntomas de la picadura real y los de la "picadura psicológica" se pone de manifiesto cuando, ante la presencia amorosa de Pepa, Roque deja de quejarse. Un vecino comenta que ella lo ha curado. Ante eso, otra vecina da por terminada la velada, mientras exclama:

Mal de amores, no lo curan los doctores (Beán, 1998: 28).

Pepa dice que pueden irse todos, que ella se quedará con Roque. Pero una mujer apela a la tradición y advierte que "cuan pique la tarantula, s' ha de ballar les 24 hores seguides [...] qu'estes coses són molt sagraes" ${ }^{52}$. El atarantado insiste en que ya se encuentra bien. Agradece a los presentes

\footnotetext{
49 “Ay Carmeta! Como cuando éramos jóvenes” (Beán 1998: 21).

${ }^{50} \mathrm{Al}$ igual que la tarantela, la jota constituye, en alguna de sus formas, una danza erótica de cortejo. Véase Beán (1998: 21).

51 "No llores, Roque, que me partes el corazón. Ya cantaré y bailaré sin parar, hasta que se te pase" (Beán 1998: 25).

52 "Cuando pica la tarántula, hay que bailar las veinticuatro horas seguidas [...], que estas cosas son muy sagradas" (Beán 1998: 28).
} 
sus desvelos, y los anima a que se retiren. Roque y Pepa se quedan solos y esta vez ella le declara su amor de forma directa: "Te vull, te vull molt, Roque" 53 . También le confiesa que se alegra de que le haya picado la tarántula por haber supuesto una buena ocasión para su encuentro íntimo. Sin embargo, en el momento más inesperado, Roque vuelve a gritar de dolor y le ruega a Pepa que vaya "a buscar gent" para que le canten y bailen hasta que se cumplan las veinticuatro horas. Una vez congregados de nuevo, un vecino canta en son de jota:

Cuan la tarantula pique,

s'han de pagar'ls mamarrons,

han de dar tota la magra,

y élls s'han de raure'ls garrons ${ }^{54}$.

El canto es contestado a coro por todos los asistentes, lo que sirve de conclusión final a la obra:

La tarantula pique y fa mal, casi sempre segant u trillant, ella sempre mire de achampar, y pregant si ña algun descuidat. Ya li ha picat, ya li ha picat, a Roque li ha picat, no l'ham de dissar, no l'ham de dissar, li ham de cantar y ballar. No mo n'anirem, Hasta que'l curem ${ }^{55}$.

El tema del fracaso sentimental y su resolución tras la crisis resulta, por tanto, esencial en la pieza, lo que implica una interpretación tradicional del tarantismo más allá del puro encuentro fortuito de la araña y su víctima.

Una estrecha relación entre la picadura de la tarántula y ciertos conflictos, casi siempre de tipo amoroso, servía también de fondo argumental en algunas comedias cortas del Siglo de $\mathrm{Oro}^{56}$. Así, por ejemplo, en el entre-

53 "Te quiero, te quiero mucho, Roque" (Beán 1998, p. 28).

54 "Cuando la tarántula pica,/ hay que pagar el festejo,/ tienen que dar toda la carne,/ y sólo les queda el "garrón" (Beán 1998: 31).

55 "La tarántula pica y hace daño,/ casi siempre segando o trillando,/ ella siempre está al acecho,/ esperando a algún descuidado./ Ya le picó, ya le picó,/ a Roque le ha picado,/ no lo abandonaremos,/ no lo abandonaremos,/ le hemos de cantar y bailar./ No nos iremos,/ hasta que lo curemos" (Beán 1998: 31).

${ }^{56}$ En el entremés de Pedro Calderón de la Barca, La Franchota, la tarantela se asocia a la picardía de una joven, falsa limosnera, que se finge peregrina y que, no sólo 
més de Luis Vélez de Guevara Los atarantados, una ardorosa joven, impaciente por encontrar marido, ha de elegir entre un sacristán y un viejo, decidiéndose finalmente a favor del más rico, propietario de un coche, aunque ello suponga renunciar a sus inclinaciones amorosas ${ }^{57}$. Según uno de los personajes de la obra, la muchacha "es de las atarantadas/ que la picó en el cerebro/ una tarántula enorme,/ y ansí baila sin remedio" (Urzáiz 1997: 143). Como es de esperar, la joven acaba montando en el coche del viejo, lo que induce a una niña a cantar un baile de atarantados con el que termina la pieza:

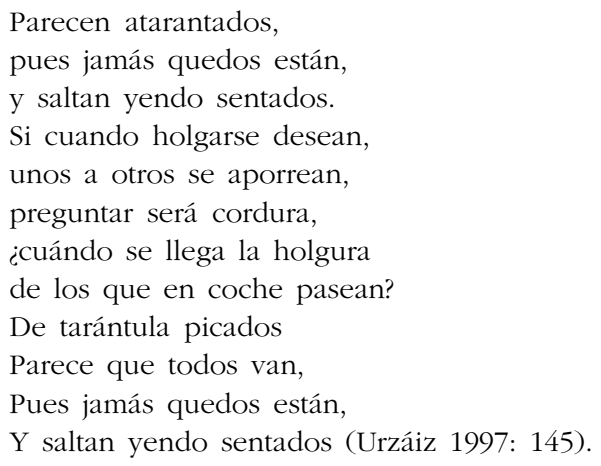

\section{COMPATÍA Y REGOCIJO}

Los dolores atribuidos a la tarántula provocaban en sus víctimas la impresión de encontrarse en trance de muerte. Según el último picado de Fraga: "Sentía un ahogo en el corazón, y no me moví en las veinticuatro horas". Durante el largo camino en carro desde el monte a la localidad, no dejó de exclamar: “Por qué no me muero y no padezco tanto?”. El sentimiento de muerte experimentado por la mayoría de los afectados no escapaba a la conciencia del resto. Como relataba Cid, en el diario del doctor que en 1767 atendió a un atarantado sevillano, se leía: "Ya era la una de la tarde quando yo llegué y me encuentro, no con un hombre, sino con un cadáver" (Cid 1787: 222).

Ante la congoja del atarantado y de sus familiares más cercanos, la res-

habla mucho, deprisa y sin orden, sino que también baila la tarantela: "[Alcalde] ¡Ay, que Franchota! ¿De qué vivís? Decid... [...] [Franchota] ¡Oh, bagatela! De cantare, cantiña, tarantela".

57 "Coche quiero, aunque me lleve el diablo". La pasión de algunas mujeres por los coches se plasmó abundantemente en la literatura del siglo xVII, y su parodia era un lugar común en las críticas misóginas (Urzáiz 1997: 142 y 154). 
puesta vecinal consistía en acudir lo antes posible para compadecer y acompañar a los perjudicados. La participación decisiva de la comunidad podría rastrearse en la obra de Cid a través de la amplia gama de términos referidos a la reacción provocada por el dolor que incluían el prefijo con-: "la mucha gente que concurría"; "un concurso numeroso del pueblo"; "llegó el juez [...] a la cama del doliente, cuyo aspecto y situación deplorable le contristô"; "gritaba el enfermo [...] que se moría sin remedio [...] de tal modo que se conmovió el pueblo", etc. (Cid 1787: 143, 149, 150 y 173) (la cursiva es mía).

Según Pedro Agustín Pérez, cuando él mismo fue picado en el año 1943, "había más de trescientos, que llenaban la calle". Y en palabras de Conchita y Carmen Salarrullana, "acudía todo el pueblo: de día, niños; de noche, mayores; y, sobre todo, los de la rondalla". Dichas afirmaciones exigen algunas matizaciones, pues, de acuerdo con otros testimonios, en cierta ocasión una familia prefirió quedarse a solas, lo que condujo a una situación sin salida: "A la primera mujer de un tal Pedro Sisó le picó la tarántula estando embarazada. En su casa no creían y no le hicieron nada, y a la semana se murió" 58 . No obstante, dicha historia se contaba como una excepción que confirmaba la regla de la solidaridad como terapia: "Ella estaba en estado, fue la única mujer que no quisieron que se tocara, y murió" 59 .

Así, pues, la creencia en el poder de la compasión, de la condolencia o compatía era el fundamento que permitía superar la crisis, y a partir del cual se elaboraba el ritual del canto y el baile, característicos de la fiesta. La convicción respecto a la bondad de dicho ritual era mayoritaria, pero también había quienes no la compartían. Tanto los representantes de la ciencia como los de la religión católica ("doctores, curas y beatas", en palabras de los informantes) desconfiaban del método popular, aunque al mismo tiempo mostraban una actitud de tolerancia, vista su incontestable eficacia.

Según Juan Antonio Labrador y Francisca Alba, "una vez, dos médicos de Fraga que estaban en el café, al enterarse, dijeron: 'Vamos a ver el cachondeo de esta gente'. Al llegar, hicieron parar a los músicos: 'Paren la orquesta', y la enferma, lamentándose. 'Toquen', y la enferma seguía bien. Al final, dijeron: 'Sigan tocando"'. Según otro episodio relatado por Andresa Beán, "cuando yo era pequeña fuimos todos los niños a la calle del enfermo. Había un médico jorobado que se llamaba Ribera; se hizo paso entre la gente, y se puso a cantar y a bailar como de burla. Nosotros nos burlábamos de él, jorobado como era".

En cuanto a la actitud de la Iglesia católica, según Andresa Beán, "los

\footnotetext{
58 Testimonio de Jorge Costa y Andresa Beán.

59 Testimonio de Juan Antonio Labrador, Francisca Albá y Carmen Morer.
} 
curas no se quejaban ni lo alababan; ni entraban, ni salían". Y, en palabras de Carmen Morer: "La Iglesia no creía con esto, y las beatas lo criticaban. Una vez, una beata, amiga de la enferma, los hizo retirar, y luego los tuvieron que ir a buscar a los músicos". De acuerdo con Pedro Agustín Pérez, cuando él fue picado, "acudieron todos los de Fraga" e "hicieron como una fiesta: guardia civil, sargento, médicos, alcalde, pero no los curas ni las beatas".

A diferencia de la asimilación católica del fenómeno en Italia a través del culto a San Pablo como protector de los atarantados, a cuya capilla de Galatina acudían cada 29 de junio muchos de ellos buscando remedio a sus males $^{60}$, el tarantismo ibérico no halló una fórmula que aunara la religión oficial y la práctica popular. La fiesta de la tarántula (celebrada sin la bendición, pero también sin la condena, de las autoridades eclesiásticas españolas) constituía un ritual pagano que cada verano volvía a renovarse en torno al lecho de la víctima de la araña. Según Juan Antonio Labrador y Francisca Alba, en Fraga, "cada año había uno o más"; según Pedro Agustín Pérez, "cada año había dos o tres"; y, en palabras de Jorge Costa y Andresa Beán, "la gente quería que cada año hubiera uno, pero no de la casa, claro".

Por lo general, la tarántula no volvía a picar o morder a los mismos individuos (recidiva o re-mordimiento estudiado por De Martino en Italia), aunque sí se daban algunos casos ("a uno le picó dos veces"61). Lo importante era la coartada que suponía la existencia de, al menos, un picado cada verano, para que la comunidad celebrara su fiesta, lo que quizás pudo inducir en ocasiones al fingimiento de la picadura real. La reiteración anual del rito como marco simbólico que permitía encauzar determinadas crisis individuales puede observarse en una interesante comparación hecha por dos informantes. Según Conchita y Carmen Salarrullana:

así como en Fraga cada año había por lo menos un picado, cada año había también el ahogado de Santa Ana. Solía coincidir que alguno se ahogaba hacia el 26 de julio, que era el día de la santa, pues se acostumbraba a ir al río a nadar, después de comer. Una vez, un chico de catorce años se hizo el ahogado y se escapó de casa. Lo encontraron en Logroño y desde entonces lo llamaron "El ahogado".

Como ha observado Clara Gallini en Cerdeña, la picadura de la tarántula era un mal que amenazaba profundamente a todos, pero también suponía

\footnotetext{
${ }^{60}$ Para De Martino, el intento de cristianización del tarantismo constituyó un fracaso, ya que, en San Pablo de Galatina, lo que había era "una confusa aglomeración de crisis individuales, sin horizonte, el desorden y el caos. En la capilla no había música, ni cintas de colores, ni el recogimiento del domicilio, ni todo ese simbolismo del exorcismo musical en acción, y en ausencia del tradicional dispositivo de evocación y liberación, los atarantados naufragaban" (De Martino 1999: 116).

${ }^{61}$ Testimonio de Pedro Agustín Pérez.
} 
la ruptura de un tiempo monótono de la vida campesina, gracias a un suceso insólito que terminaba convirtiéndose en espectáculo (Gallini 1988: 88-91). Cierto es que, como ocurría en Fraga, se trataba de un espectáculo ambiguo, donde se mezclaban las risas y las lágrimas, y donde resultaba necesario encontrar un difícil equilibrio entre la compasión y la fiesta. En el fondo, constituía una distracción, a medias entre lo grotesco y lo tragicómico, pues existía un gran contraste entre la alegría y el regocijo de la mayoría, y el dolor del enfermo. Dicho contraste era interpretado, no obstante, como una necesidad, ya que la risa, los cantos y los bailes eran precisamente lo que conseguía consolar al doliente. Entender la diversión como algo saludable, incluso frente a la enfermedad y la muerte, ilumina el abismo entre dos universos culturales: el tradicional, ya desaparecido, y el nuestro.

Para Francisco Xavier Cid, el hecho de que los picados de la tarántula se restablecieran mediante la música se explicaba por la variedad que ésta aportaba, en ausencia de otros estímulos, como viajar y experimentar nuevas sensaciones $^{62}$. El dolor que dejaba la picadura de la tarántula era comparable a una obsesión o idea fija, y contra las obsesiones o manías propias de la locura el único remedio era la distracción y la experiencia de la pluralidad o, en palabras de otro sabio y contemporáneo inglés, el célebre escritor Samuel Johnson, "to diffuse yourself" (Johnson 1999: 86) ${ }^{63}$.

Con la tarántula como protagonista simbólica de la fiesta celebrada en su honor, y en torno al lecho de la víctima elegida cada año, una extensa y excitante variedad de objetos servía para exorcizar todo tipo de ideas y conflictos arraigados no sólo a nivel individual, sino también colectivo. De este modo, la diversión, entendida como desviación de las preocupaciones, constituía en sí misma una forma de caridad, cada vez más difícil de reconocer en nuestros días.

62 "Uno de los remedios más encomendados en la curación de la manía, melancolía y otras castas de delirios es la variedad de objetos [...] Es necesario viajar si se ha de llevar la idea que promete el remedio [...] Pero [...] todo lo que este incómodo y dispendioso remedio promete [...] muy bien se puede conseguir con la música [...] Su intención es borrar las ideas que, por antiguas, están profundamente radicadas en la imaginativa [...] Si hubieran reflexionado con seriedad los médicos en la música y su modo de obrar, hubieran sustituido al penoso, largo y dispendioso remedio del viajar el barato, fácil, inocente y eficacísimo de la música, puesto que en cada momento se renuevan de mil modos los objetos" (Cid 1787: 298-300 y Amades 1949).

63 "When the clouds of sorrow gather over us, we see nothing beyond them, nor can imagine how they will be dispelled: yet [...] our minds, like our bodies, are in continual flux. [...] Do not suffer life to stagnate; it will grow muddy for want of motion; commit yourself again to the current of the world, [...] or learn to diffuse yourself in general conversation" (Johnson 1999: 85-86). 


\section{BIBLIOGRAFÍA CITADA}

Adell Castán J. A. y García Rodríguez, C. 1988. Fiestas tradicionales del Altoaragón. Huesca: Instituto de Estudios Altoaragoneses.

Almendros Toledo, J. M. 1987. "Un caso de tarantismo en Mahora". Al-Basit. Revista de estudios albacetenses 20: 205-210.

Álvarez Barrientos, J. 1988. "Música y medicina: Francisco Xavier Cid y su 'Tarantismo observado en España'(1787)”. Revista de Dialectología y Tradiciones Populares 43: 39-46.

Amades, J. 1949, "Danzas mágicas medicinales". Archivo Iberoamericano 3: 349-362.

Amelang, J. S. 2005. "Mourning becomes eclectic: Ritual lament and the problem of continuity". Past and Present 187: 3-31.

Baglivi, G. 1754 [1696]. "Dissertatio de anatomia, morsu et effectibus tarantulae", en Opera omnia medico-practica et anatomica, Dissertatio VI. Venecia, p. 314.

Beán, A. y P. 1998. La tarántula. Fraga: Amics de Fraga.

Cid, F. X. 1787. Tarantismo observado en España, con el que se prueba el de la Pulla, dudado de algunos y tratado de otros de fabuloso. Y memorias para escribir la historia del insecto llamado tarántula, efectos de su veneno en el cuerpo humano, y curación por la música con el modo de obrar de ésta, y su aplicación como remedio a varias enfermedades. Madrid: Imprenta de González.

Desplat, Ch. 2001. Sorcières et Diables en Gascogne (fin XIV - début XIXe siècle). Toulouse: Cairn.

Galán Bergua, D. 1966. El libro de la jota aragonesa. Estudio bistórico, crítico, analítico, descriptivo y antológico de la jota en Aragón. Zaragoza: Tipolínea.

Gallini, C. 1988. La danse de l'argia. Fête et guérison en Sardaigne. Dijon-Quetigny: Verdier.

García de las Mozas, A. y López Sánchez, A. 1999. "Tarantela y tarantismo en la Baja Andalucía (esbozo histórico)". Tavira. Revista de Ciencias de la Educación 16: 129-146.

García de las Mozas, A. y López Sánchez, A. 2000. "Tarantela y tarantismo en la Baja Andalucía (un esbozo histórico). Segunda parte”. Tavira. Revista de Ciencias de la Educación 17: 127-147.

González Palencia, A. 1944-1945. "La tarántula y la música (creencias del siglo XVIII)". Revista de Dialectología y Tradiciones Populares I: 54-87.

Gruszcynska-Ziólkowska, A. 2007. "La danza de la araña. En torno a los problemas del tarantismo español (1)". Revista de Folklore 317:147-165.

Johnson, S. 1999. The history of Rasselas, prince of Abisinia. Oxford: University Press.

Junceda, L. (ed.). 1998. Diccionario de refranes, dichos y proverbios. Madrid: Espasa Calpe.

Kircher, A. 1643. Magnes, sive De arte magnetica, opus tripartitum, Roma.

Lafoz Rabaza, H. 1990. Cuentos altoaragoneses de tradición oral. Huesca: Instituto de Estudios Altoaragoneses.

Laín Entralgo, P. 1958. La curación por la palabra en la Antigüedad Clásica. Madrid: Revista de Occidente

L’Échevin, P. 1981. Musique et médecine. París: Stock.

León Sanz, P. 1991. "Literatura médica española sobre musicoterapia en el siglo XVIII". Nassarre VII (2): 73-155.

León Sanz, P. 1997. "Musicoterapia y observación clínica en la España del siglo XVIII". Nassarre XIII (1-2): 69-122.

León Sanz, P. 2000. "Medical Theories of Tarantism in Eighteenth-Century Spain”, en Peregrine Horden (ed.), Music as Medicine. The History of Music Therapy since Antiquity: 291-292. Aldershot: Ashgate. 
Martino, E. De. 1975. Morte e pianto rituale. Del lamento funebre antico al pianto di Maria. Turín: Bollati Boringhieri.

Martino, E. De. 1999. La tierra del remordimiento. Barcelona: Bellaterra.

Mestre y Marzal, C. 1843. El tarantulismo, o sea, descripción de la enfermedad producida pr la picadura de la tarántula, y su método curativo. Madrid: Imprenta de Estellés.

Mexía, P. 1989 [1540]. Silva de varia lección. Madrid: Cátedra.

Mitri, G. L. Di (ed.). 2000. Quarant'anni dopo De Martino. Il Tarantismo (Atti del convegno Galatina 24-25 ottobre 1998). Besa: Nardò.

Nelli, R. 1963. L'érotique des troubadours. Toulouse: Édouard Privat.

Orobitg, Ch. 1997. L’humeur noire: mélancholie, écriture et pensée en Espagne au XVI et $X V I I^{e}$ - siècles. Bethesda: International Scholar Press.

Piñera y Siles, B. 1787. Descripción histórica de una nueva especie de corea o baile de San Vito, originada de la picadura de un insecto que, por los fenomenos seguidos a ella se ha creido ser la tarántula. Enfermedad de que ha adolecido y curado a beneficio de la música Ambrosio Silván. Narración de los sintomas con que se ha presentado y exposición fiel y circunstanciada del plan curativo que se ha practicado. Madrid: Imprenta de Benito Cano.

Ponzetti, F. 1521. De venenos. Roma.

Robledo, L. 1979-1980. "Poesía y música de la tarántula". Cinco Seis. Revista ilustrada de información poética 5-6: 224-232.

Rouget, G. 1990. La musique et la transe. Esquisse d'une théorie générale des relations de la musique et de la posesión. París: Gallimard.

Rouget, G. 2000. "Tarantismo, 'musica giusta' e iniziazione”, en G. L. Di Mitri (ed.), Quarant'anni dopo De Martino. Il Tarantismo (Atti del convegno Galatina 24-25 ottobre 1998). Besa: Nardò, vol II.

Sabuco de Nantes, O. 1587. Nueva Filosofía de la Naturaleza del hombre.

Satué Oliván, E. 1988. Las romerías de Santa Orosia. Zaragoza: Diputación General de Aragón.

Schneider, M. 1948. La danza de espadas y la tarantela. Ensayo musicológico, etnográfico $y$ arqueológico sobre los ritos medicinales. Barcelona: CSIC.

Schneider, M. 1998. El origen musical de los animales-símbolos en la mitología y la escultura antiguas. Siruela: Madrid.

Tamblé, M. R. 2000. "Tarantismo e Stregoneria: un legame possibile", en G. L. Di Mitri (ed.), Quarant 'anni dopo De Martino. Il Tarantismo (Atti del convegno Galatina 2425 ottobre 1998). Besa: Nardò, vol. I.

Tausiet, M. 2002. Los posesos de Tosos (1812-1814). Brujería y justicia popular en tiempos de revolución. Zaragoza: Instituto Aragonés de Antropología.

Tausiet, M. 2004. Ponzoña en los ojos. Brujería y superstición en Aragón en el siglo XVI. Madrid: Turner.

Turchini, A.1987. Morso, morbo, morte. La tarantola fra cultura medica e terapia popolare. Milán: Franco Angeli.

Urzáiz Tortajada, H. 1997. "Un entremés olvidado de Luis Pérez de Guevara: Los atarantados", Criticón 71: 127-157.

Zapater, A. 1988. Historia de la jota aragonesa. Zaragoza: Aguaviva, 3 vols.

Fecha de recepción: 3 de mayo de 2008

Fecha de aceptación: 24 de marzo de 2009

RDTP, vol. LXIV, n. ${ }^{\circ}$ 2, pp. 63-90, julio-diciembre 2009, ISSN: 0034-7981, eISSN: 1988-8457, doi: 10.3989/rdtp.2009.005 